Tarih Kültür ve Sanat Araştırmaları Dergisi

Revue des Recherches en Histoire Culture et Art

مجلة البحوث التاريخية والثقافية والفنية
Vol. 7, No. 1, March 2018

Copyright (C) Karabuk University

http://kutaksam.karabuk.edu.tr

\title{
DOI: 10.7596/taksad.v7i1.1448
}

Citation: Andrienko, N., Lukash, S., Tersakova, A., \& Papernaya, N. (2018). Problem of Structure Planning of the Russian National-Civilizational Identity: Social - Pedagogical Aspect of the Cossacks Pedagogics. Journal of History Culture and Art Research, 7(1), 34-39. doi:http://dx.doi.org/10.7596/taksad.v7i1.1448

\section{Problem of Structure Planning of the Russian National-Civilizational Identity: Social - Pedagogical Aspect of the Cossacks Pedagogics}

\author{
Nadezhda K. Andrienko', Sergey N. Lukash², \\ Angela A. Tersakova ${ }^{3}$, Nina V. Papernaya ${ }^{4}$
}

\begin{abstract}
One of the most important problems of modern nation building in Russia is to reduce the level of disintegrational potential of ethnic and religious differences in Russian society. In this regard, the Russian scientific discourse has actualized the problem of the formation in Russia a national-civilizational identity capable of overcoming ethnic and confessional contradictions in the society. In the socio-pedagogical interpretation of this problem, the actual direction is the search for appropriate socio-cultural phenomena, the creation of pedagogical concepts and models based on the successive transfer of sociocultural experience. One of such phenomena is the culture of the Russian Cossacks, which is the expression of the socially significant values of Russian culture that are in demand today and reflect the image of Russia as a Eurasian and Russian civilization. In the article, the culture of educational potential of the Russian Cossacks as a sociocultural phenomenon of the Russian civilization, which has transethnic foundation, is analyzed. As an up-to-date tendency is presented the modern conception of sociocultural education - the Cossacks pedagogics, which is based on successive transfer of sociocultural experience and which realizes national and cultural traditions of civilizational unity of the Russian community in the Russian educational paradigm.
\end{abstract}

Keywords: Cultural-historical area, the Nation-building, Ethnic-national identity, Pedagogy of the Cossacks, Multiconfessional formations, the Russianhood.

\footnotetext{
${ }^{1}$ Armavir State Pedagogical University (ASPU), street of the Rose Luxembourg, Armavir, Russia. E-mail: nadi2007@mail.ru

${ }^{2}$ Armavir State Pedagogical University (ASPU), street of the Rose Luxembourg, Armavir, Russia. E-mail: lukash.serg@yandex.ru

${ }^{3}$ Armavir State Pedagogical University (ASPU), street of the Rose Luxembourg, Armavir, Russia. E-mail: kaf_tipiop@mail.ru

${ }^{4}$ Armavir State Pedagogical University (ASPU), street of the Rose Luxembourg, Armavir, Russia. E-mail: kaf_tipiop@mail.ru
} 


\section{Introduction}

The Strategy of scientific-technological development of the Russian Federation, ratified by presidential edict in December, 2016, as one of priorities highlights possibility of effective response of the Russian society to the global challenges of present time considering interaction of a person with social institutes, including application of methods of liberal and social sciences. One of the global challenges of Russia in her historical and cultural retrospective is the problem of national unity of the Russian society.

Historically, Russia develops a unique project of nation-building, based on annexation of huge territories and its ethnic groups, its association in a single cultural-historical area at that preserving, multiplying and developing ethnic unicity of all nations - parts of the Russian Federation. Liberal reforms, which swept Russia in the beginning of 1990s, called for appearance of a new project of nation-building, related with development of civil nation on the basis of civil society, which, however, has not been realized due to some social-cultural circumstances. In the beginning of 21st century in scientific discourse was proposed the project of nation-building, oriented for simultaneous development of the Russian nation as civil and political, at that preserving cultural diversity of the Russian nations. As the result of the above project realization in Russia has been partially built a political nation with predominance of the state-civil identity and with significant elements of the ethnic-national identity (especially in the national Republics). Finally, the state-civil identity proved to be insufficient to reduce disintegrational potential of ethnic-confessional differences in the Russian society, what has made the issue actual in development of new projects of nation-building and models of national integration.

In this regard in the Russian scientific discourse has been made actual a problem related to building in Russia of transethnic nation-civilization and respective construction of the national and civilizational identity which is able to overcome ethnic and confessional contradictions in society (Lubskiy, 2015).

In the social-pedagogical interpretation of this problem as an up-to-date tendency is presented searching of the relevant sociocultural phenomena of the Russian civilization, which have transethnic foundation, creating of pedagogical conceptions and models, which are based on successive transfer of sociocultural experience and which realize national-cultural traditions of civilizational unity of the Russian community in the Russian educational paradigm

In educational sphere the main factors which promoted definition of processes of national consolidation and creation of a unified system of national education were the Federal state educational standards as well as conception of spiritual and moral education of a Russian national personality, which determined national educational ideal as a moral personality, "deep-rooted in spiritual and cultural traditions of multicultural nation of the Russian Federation (Danilyuk, Kondakov, \& Tishkov, 2009, p.5). The Conception determines also substantial objectives of spiritual and moral up growth of a personality, education and socialization, such as "basic national values, kept in social-historical, cultural, family traditions of the Russian multicultural nation (Ibid., p.29).

Therefore, the standards and conception determined not only purposes, objectives and competencies, but also revealed imperatives of the national educational system construction considering civilizational particularities of Russia as a multinational and multiconfessional country, treasuring her multinational composition.

\section{Methods}

Building and shaping national identity are abundantly discussed in the academic literature. The academia inclines to accept that nationhood and nationalism are subjects of the long-term political, economic, and cultural changes (see Calhoun, 1993; Brubaker, 2004; Ting, 2008; Yilmaz, 2013). In this regard one of the topical research tasks is - determination of the relevant methodological approaches, where ideas of the Russian national-civilizational identity may be realized most fruitfully, revelation of the backbone phenomena, composing the integral sociocultural contexture of the Russian society. One of such phenomena is the culture of Russian Cossacks, which is to a certain extent a spokesman of currently demanded socially significant values of the Russian culture, representing Russian character as Russian civilization (Lukash, 2014). Cossack culture is studied in our work with the help of methods of theoretical 
analysis, comparison, systematization and generalization from the standpoint of phenomenological, culturological, axiological and civilizational approaches.

\section{Results}

In the course of its development the culture of Cossacks, evolving from a monotheistic community to a kind of Russian nationwide phenomenon, inclusive representatives of different nations and religious confession (some of Cossacks troops by the middle of the 19th century presented multinational and multiconfessional formations), produced some certain social paradigms, which have got metacultural nature, transcending in its values the sub-ethnic and class nature of Cossacks, having become the centers of nationwide unity and cohesion of the Russian people (Lukash, 2016).

One of such paradigms is an idea of the "Russianhood", which refers to achieving by nations, comprising the Russian state, of the Russian consciousness, their integration in the cultural-wide Russian domain, recognizing Russia as their Motherland, producing of the general cultural-educational paradigms. The conception is based on postulates of existing of the other Russia alongside with the official "imperial" Russia - which is always ready for interactions with the other regions, treasuring her main wealth multinational composition (Vinogradov, 2006).

The Cossacks, as a distinct military class and bearer, to a certain extent, of the Russian civilizational idea, in their status had all features of the "Russianhood", serving as a first, proven in deeds algorithm of "cooperation" between Russia and nations, which she has incorporated. Within conception of the "Russianhood" the Russian state usually serves as a mediate factor and the leading importance is assumed by direct contacts between nations, their influence and cooperation. "If the official "commonwealth" dictated and accepted only one ("Ioyal") tone, then the RUSSIANHOOD incarnated in more diversified and flexible form of interaction and even inter-influence (Vinogradov, 2002). In this context the Cossacks, serving as advance guard of Russia's progress southward and eastward, successfully took upon themselves a mission of the "Russianhood", proudly representing the Russian culture and performing cultural borrowings from new nations.

By the mid-19th century the Cossacks became an active guide and spokesman of the "Russianhood" idea towards broadening of the Russian civilization borders, in respect of newly annexed nations, proudly representing the Russian culture and performing cultural borrowings from new nations, hence performing an important civilizational mission, accepting nations into the Russian cultural-historical area, serving as a kind of "melting-pot" in the process of shaping of the Russian national identity (Lukash, 2016).

Another certain achievement of the Cossacks culture is its substantial contribution in consolidation of the public conscience over creation of a perfect man character of the Russian national culture. Pedagogical conceptualization of this connotation from the point of view of historical-culturological, civilizational approach is significant for the contemporary native education since a person of culture is an aim of the personality-oriented education of culturological type.

Prompt excursus of studies of the works on the problems of "a person of culture", represented in symposium of the $4^{\text {th }}$ International pedagogical forum called "Education of a citizen, a person of culture and morality - is foundation of the social technology of modern Russia development", gives us the following edges: "global class", "network socialization", "lingual personality", "multicultural personality", "cosmopolite". The lack of a common understanding of the meaningful content of the concept of a "man of culture" only exacerbates the growing contradiction between the Russian cultural and pedagogical tradition, where spiritual and moral education has always been considered as a basic part of education, and a modern level of educational practice that, for a variety of reasons, is one of its important senseforming links - spiritually moral upbringing.

\section{Discussion}

The Russian education has been always distinguished by spiritual and moral component, which serves as a kind of mental constant. In this context in the Russian educational situation are intensified disputes over 
one of the fundamental methodological contradictions - dialectic of traditional and something that tries to come to us in the likeness of innovation, but usually bringing an obvious destructive effect.

Solution of the above contradiction is possible and lies in methodological rethinking of social processes of the post-modern society. In particular, the common tendency of post-modernity, which successfully resists to cultural unification and detraditionalization, is glocalization - dialectic interaction of the local and the global, which stipulates the local processes shift to the level of the global and their transformation into processes, which retain and enhance the regional differences and diversities. Glocalization considers orientation to the past as one of characteristics of the post-modernity, because "return to achievements of the past eras, rethinking of accumulated experience give the mankind a chance to reach the true progress (Guliga, 2003: 21). At all pedagogical novations the call to wisdom of the past and tradition is quite significant, because "...one cannot forget that education has to hold the national tradition, which is the basis of restitution of the culture-like forms of the modern society esse" (Bondarevskaya 2007: 19).

Considering reliance on the Russian cultural-historical pedagogical tradition and also such basic Russian national values as civic consciousness, patriotism and justice we should refer to the conceptual analysis of those ideas, which compose the united substance of the Russian culture and civilization, serve for wholeness and "russianhood" of our motherland, fastening our nation in organic whole. And filling of the conception of "a person of the Russian culture" we should primarily search in this area. The culture of the Russian Cossacks phenomenon comes before us as preciously this.

Our historical and pedagogical researches show, that ideals of the Cossacks lifestyle have its followers among representative of different classes: peasants, bourgeois, upper class and even aristocracy. The great Russian writers such as A.S. Pushkin, M.Y. Lermontov, N.V. Gogol and L.N. Tolstoy in search of samples of the best peoples fate referred to the Cossacks, their social order and values, because they read in them acceptable modes of life and destination for the Russian society, hence forming the perfect character-ideal of a person of the Russian national culture (Lukash, 2014).

The natural process of the Russian nation-building, which has been also conveyed by the Cossacks culture, was intermitted in 1917 by the well known events of the home history. However, revival of the Cossacks in the 1990s discovered their another side - pedagogical, educational potential of the Cossacks culture, which is based on the values of the Russian democracy, on the nationhood traditions and devotion to the Motherland. Intermitted civilizational mission of the Russian Cossacks culture in the process of creation of the Russian national identity continued in contemporary phenomenon of the Cossacks pedagogy, which is based on traditions of the Cossacks culture (Lukash, 2014). By dynamic development in educational environment of the regions and districts, involving hundreds of educational institutions, tens of thousands of participants (including representatives from the other nations), the modern Cossacks pedagogy restores in educational environment of the wide society the values of the Russian civilizations, which are presently demanded: love to Russia and to the homeland, devotion to the Motherland "not for fear, but for conscience", democracy, nationhood, toleration, and pluralism.

\section{Resume}

Thereby from the point of view of ethnology and social pedagogy, it is rightful to talk about the Cossacks culture as an integrating part of the Russian nation. In its cultural genesis the Cossacks, being an ethnicsocial phenomenon, also served a very important congregative function in creation of the Eurasian community - Russian nation, laying preconditions for creation of the Russian national-civilizational identity, which has overcome ethnic and confessional differences in the Russian society.

Such a message is quite significant, because it establishes historical-social links and congregative paradigms, which serve for integrity of the Russian nationhood and unity of the Russian people, which is a very important factor of the modern Russia nation-building. Such backbone values of the Cossacks metaculture as "Devotion to the Motherland not for fear, but for conscience"; democratic foundations of the world order, toleration, free development of personality, patriotism and sovereignty; labor as the lifestyle base are demanded in social life of the modern Russian society, which tries to find adequate responses for the challenges of modernity. 
Specification of the Cossacks culture educational potential is quite eligible, because it is considered as the Russian national cultural and educational value, which externalizes the paradigm of the "Russianhood", democratic vector of the Russian social development and creates favorable educational environment for transformation of traditions of the past into innovations of the present day (Lukash, 2016).

The educational intention of the Cossacks pedagogy, which is realized in the Russian educational environment of the present, is a person of the Russian national culture, who is open for perception of the different cultures and personifies traditions of the "Russianhood", measuring his/her actions accordingly to the values, which are historically natural for the Cossacks culture, namely: freedom, democracy, patriotism, social responsibility, cultural pluralism, devotion to the Motherland; realizing him/herself in different professional, civil, social, family and other relations.

\section{Conclusion}

In view of the above mentioned, the modern Cossacks pedagogy should be advisably interpreted as a recuperative factor of the Russian national solidarity. In this context the topical scientific mission is theoretical elaboration and experimental approbation of the social-pedagogical educational model of a person of the Russian national culture on the basis of educational potential of the Russian Cossacks culture, which substantiates the national and cultural traditions of civilizational unity of the Russian society.

\section{Conflict of Interests}

The authors confirm that the presented data does not contain the conflict of interests.

\section{References}

Bondarevskaya, E. V. (2007). The strategy and conception of the student education in the cultural and educational environment of Pedagogical Institute SFU. Rostov-on-Don.

Brubaker, R. (2004). Nationalism reframed: nationhood and the national question in the new Europe ( $7^{\text {th }}$ ed.). Cambridge: Cambridge University Press.

Calhoun, C. (1993). Nationalism and Ethnicity. Annual Review of Sociology, 19, 211-239.

Danilyuk, A. Y.; Kondakov, A. M. \& Tishkov, A. M. (2009). The Conception of spiritual-moral development and education of a Russian citizen identity in the general education region: project. Moscow.

Gulyga, A. V. (2003). The Russian idea and its authors. Moscow.

Lubskiy, A. V. (2015). The state - civilization and the national - civilizational identity in Russia. Journal of humanities of the south of Russia, 2, 30-45.

Lukash, S. N. (2014). The Cossacks of the Russian South: from tradition to innovations: monograph. Armavir.

Lukash, S. N. (2016). The "Russianhood" as the basic paradigm of the person of culture. News of Volgograd state pedagogical University, 1, 60-66. 
Ting, H. (2008). Social construction of nation - a theoretical exploration. Nationalism and ethic politics, 14(3), 453-482.

Vinogradov, V. B. (2002). The russianhood as a paradigm of the North Caucasian historical and cultural unity in composition of Russia the russianhood in the history of Northern Caucasus. Armavir.

Vinogradov, V. B. (2006). The process of perception of the "russianhood" in historical fates of the Northern Caucasus (historiographic review). The Russian Northern Caucasus: facts, events, people, (pp. 14-17). Moscow: Armavir.

Yilmaz, S. (2013). State, politics, and religion: effects of political and social change on the relationship between state and religion in Turkey, 2002-2012. Dissertation in sociology. University of Pittsburgh. 